\title{
Fishes of Lakshadweep archipelago: new records, review and a revised checklist
}

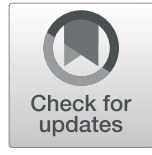

\author{
Rajkumar Rajan ${ }^{1 *}$, P. T. Rajan², S. S. Mishra ${ }^{3}$, Abdul Raheem C. N. ${ }^{4}$, Shrinivaasu S. ${ }^{1}$, Surendar C. and Damodhar A. T.
}

\begin{abstract}
Extensive studies on fish diversity in Lakshadweep waters began with Jones and Kumaran's in 1964. Reports after these authors were sparse and sporadic until the turn of this century. Although recent reports have increased the tally, targeted studies are lacking, and there is a possibility of listing more species for this region. Studies on the diversity and abundance of fishes are due, given the atoll system undergoing rapid changes: structural decline due to several bleaching related coral mortality events, changes in the seagrass meadows, and the increase in fishing reef-associated species. These circumstances call for a revised checklist of fishes for this region, for the latest dates back to 1991. Thus, we present an inventory of ichthyofauna of Lakshadweep atolls based on published literature and incorporating 15 new species records identified through a rapid survey. The new species records for this region are presented here with the diagnostics of these species. The checklist shows 856 species of 432 genera, 43 orders, and 144 families known from these islands, including 16 freshwater forms. 49.3\% of the contribution is from 14 fish families having $>15$ species each, while the remainder 131 families contributed 52.5\%, which have $<15$ species. About 154 species belonging to 12 families are known to contribute to the commercial fisheries of these islands. The new records reported in this work for this region are found in the Maldives, and Sri Lanka proves the zoogeographical affinity of these two regions with the Lakshadweep archipelago.
\end{abstract}

Keywords: Fish diversity, Lakshadweep Islands, New records, Revised checklist, Taxonomy

\section{Background}

Lakshadweep archipelago is the northernmost chain of atolls at the Laccadive-Chagos ridge, situated between $12^{\circ}-8^{\circ} \mathrm{N}$ and $71^{\circ}-74^{\circ} \mathrm{E}$ in the Arabian Sea, and separated from the Maldives by the nine-degree Channel, consists of 15 atolls and three prominent submerged reefs. The atolls have a reef area of $933.7 \mathrm{~km}^{2}$, including a lagoon area of $510 \mathrm{~km}^{2}$ (Bahuguna and Naik 1994). The islands are small, from $0.1-$ to $4.4 \mathrm{~km}^{2}$ in size, and together with the islets, cover a total land area of 32 $\mathrm{km}^{2}$. The lagoons support a rich growth of benthic macroalgae and seagrass, and hitherto, more than 100 species of flora have been recorded (Rao 1991). The atoll reefs share much of their fauna with the Maldives, with some faunal affinity to mainland India's reefs (Rao

\footnotetext{
* Correspondence: raj@zsi.gov.in

${ }^{1}$ Marine Biology Regional Centre, Zoological Survey of India, Chennai 600028, India

Full list of author information is available at the end of the article
}

1991). Coral diversity comprises 133 coral species under 44 genera, with species Acropora and Porites being common (Pillai and Jasmine 1989, Caeiro 1999). An account of 152 species of meiofauna, 69 species of Polychaeta, 17 species of Sipuncula, seven species of Echiura, 13 species of Stromatopoda, 79 species of Insecta, 168 species of Mollusca, and 72 species of Echinodermata have been so far reported, along with four species of marine turtles (Ghosh 1991). The extensive coral reefs, lagoons, and the surrounding oceanic depths contribute to this archipelago's rich and varied fish fauna. The fish diversity in these waters also receives a particular interest due to the Arabian Sea's confluence with the Indian Ocean and Western Pacific.

Alcock's (1890) account of deep-sea fishes was the first on fishes of Lakshadweep. Several works ensued: Alcock 1891, 1892, 1894, 1896, Gardiner 1901-1905, Hornell 1910, Ayyangar 1922, Ellis 1924, Burton 1940, Mathew and Ramachandran 1956, Balan 1958. Extensive works,

(c) The Author(s). 2021 Open Access This article is licensed under a Creative Commons Attribution 4.0 International License, which permits use, sharing, adaptation, distribution and reproduction in any medium or format, as long as you give appropriate credit to the original author(s) and the source, provide a link to the Creative Commons licence, and indicate if changes were made. The images or other third party material in this article are included in the article's Creative Commons licence, unless indicated otherwise in a credit line to the material. If material is not included in the article's Creative Commons licence and your intended use is not permitted by statutory regulation or exceeds the permitted use, you will need to obtain permission directly from the copyright holder. To view a copy of this licence, visit http://creativecommons.org/licenses/by/4.0/. 
however, on fishes of Lakshadweep came about only in the sixties after Jones (1964) and Jones and Kumaran (1964a, 1964b, 1965a, 1965b, 1966, 1967, 1968, and 1970). Jones (1969) prepared a 'Catalogue of fishes from Laccadive Archipelago' based on the reference collections in Central Marine Fisheries Research Institute (CMFRI), listing 528 species. Later, Jones and Kumaran (1980) published a comprehensive account describing 603 fishes from Lakshadweep. Studies after Jones and Kumaran's have been sparse, except Venkateswarulu and Ilango (1982), who added 16 species, and Balachandran and Nizar (1989) added three more. The compiled checklist by Rao (1991), at this time, presented 740 fishes. However, at the turn of the century, several new reports from this group of islands were published, including 16 species from these island's freshwater bodies (Nasser 1999, Nasser et al. 2002, Murty 2001, 2002, Anand and Pillai 2002, 2005, 2007, Sluka and Lazarus 2006, Ajithkumar et al. 2012, Vinoth et al. 2012, Aneeshkumar et al. 2012, 2013, Prabhakaran et al. 2013, 2013a, Randall and Bineesh 2014, Idreesbabu et al. 2014, Noushad et al. 2014, Barman et al. 2014, Joshi et al. 2011, Nair et al. 2014, Sahayak et al. 2014, Abdussamad et al. 2015, Aneeshkumar et al. 2015, Sirajudheen and Khan 2014).

Revisions of fish diversity studies are required, on an emergency basis, as the diversity in these atolls is threatened mainly due to coral decline, the disappearance of seagrass, and the shift from oceanic to reef-dependant fisheries. The coral decline is clear from previous studies: A $40 \%$ decline in coral cover over the last two decades has resulted due to the successive massive bleaching events in 1998, 2010, and 2016, with the reduction in corals like Acropora, that provide structural complexity to the reefs (Rajan et al. 2015, Yadav et al. 2018). Arthur (2004) observed changes in fish composition during the recovery phase, from 2000 to 2003, where coral affiliates like Oxymonocanthus longirostris were cited as rare, despite being commonly observed before 1998. The latest studies further confirm the impact of coral decline on fish abundance (Karkarey 2018; Rogers et al. 2017) and diversity (Komyakova et al. 2018). Secondly, the seagrass habitats in these reefs are also changing in recent years. Turtle grazing has been shown to reduce the production rates in meadows (Kelkar et al. 2013) and cause shifts in seagrass species dominance (Kelkar et al. 2013). However, the reasons for the low seagrass cover currently (Geevarghese et al. 2017) in the lagoons from the previously abundant covers (Koya et al. 2012; Nobi et al. 2012) are not clear. Healthy seagrass meadows in tropical reefs invariably sustain high fish diversity, known as nursery habitats for many fish species and support subsistence seagrass-based fishery (Gillanders 2006; Nordlund et al. 2017; Jianguo et al. 2018).
The decline in seagrass meadows in these atolls is a concern for fish diversity and fisheries. Thirdly, there is a shift in fishing practices recently, from the predominantly tuna fishery (pelagic, open ocean) to the reefdependant fishery (Karkarey 2018) forced by the current market (local) trends. Continuance of this fishery shall cause changes in fish species assemblages and may be detrimental to the reef's recovery by reducing the herbivore populations (Arthur 2004; Karkarey 2018).

By presenting the checklist, this manuscript aims to aid current and future studies on fish diversity - verify what is present now and monitor changes, which are essential given the threats to fish diversity in this region.

\section{Materials and methods}

The compiled fish species list consolidates over 125 years of accrued information from published literature, including inventories and faunistic surveys, field guides, taxonomic and fishery studies. We supplemented this review through a rapid survey covering 28 stations in four atolls (Agatti, Kadmat, Bangaram \& Bitra) from 20.11.2014 to 12.12.2014. Except for two stations each in the lagoons of Kadmat and Agatti, other stations were on the reef slope, with atleast six stations on each island. The dive time at each station varied from 1 to $2 \mathrm{~h}$. The divers noted the species sited at each station which were also photographed. A cumulative of 786 photos of fishes were taken. The fish species identified in the field were revalidated from the photos and consultations between observers. The works of Jones and Kumaran (19591980) were taken as the base and consulted to incorporate findings from other publications and our survey results. Publications of non-taxonomic nature were also considered to include several species names presented in the list (Additional file 1). The systematic arrangement of families follows van der Laan et al. (2019) with minor changes. Species in each family were arranged alphabetically. The scientific names of fishes used in the cited literature were updated following recent usage, and hence junior synonyms were omitted. The first available taxonomic reference for a species is cited with the page number. Those taken from non-taxonomic works are marked with an asterisk (*) and those from unpublished work (Ph.D. theses) are marked with a double asterisk $(* *)$. The names reported without any taxonomic information and excluded from this list are appended, citing causes for exclusion as in Additional file 2.

\section{Results and discussion}

A total of 90 species belonging to 30 families and 13 orders were recorded during the rapid survey under the current study (the list is attached as Additional file 3). Fifteen species are reported as new additions to the 
Lakshadweep reefs (Table 1), where four species, namely Sebastapistes cyanostigma (Bleeker, 1856), Zoramia virdiventer Greenfield, Langston \& Randall, 2005, Ecsenius yaeyamaensis (Aoyagi, 1954) and Naso tonganus (Valenciennes, 1835), have not hitherto been reported from Indian waters, from the Andaman Islands in the east to Lakshadweep in the west. Table 1 shows the status (yes/ no) of previous reports of the new species records in Indian waters from Andaman and Nicobar Islands and the mainland coast of India.

The diagnostics of the new species records are presented below with extracts from the original descriptions, observations in-situ and the field photographs. The original description of the species can be referred from the citation corresponding to the author(s)' name, which is cited in full. Underwater photos of these species along with the map of the photograph's location are provided in Figs. 1, 2, 3 and 4.

\section{Neotrygon indica Pavan-Kumar et al., 2018} (Indian Ocean Blue-spotted mask ray)

Neotrygon indica Pavan-Kumar, Kumar, Pitale, Shen \& Borsa, 2018, Comptes Rendus Biologies, 341 (2): 128, Figs. 1A, B and 2 (Type locality: Gulf of Mannar, Tamil $\mathrm{Nadu}$, India, $9.12^{\circ} \mathrm{N}, 79.46^{\circ} \mathrm{E}$ ).

Diagnosis: Disc is kite-like, wider than long; naked with few dorsal denticles; snout short and gently rounded; two papillae are present inside the mouth; tail is about as long as the disc with upper and lower cutaneous folds; a pair of sharp spines on the upper surface of the middle part of the tail. The body is pale brown in colour with small bright ocelli with blue centers, several dark speckles, and few scattered black spots; a conspicuous occipital mark present; underside of the disc is white; tail with black and white bands behind the sting (Fig. 1).

Distribution: Indian Ocean: India and Sri Lanka. It is usually found in sandy areas adjacent to reefs.

Remarks: The species resembles Neotrygon kuhlii (Müller \& Henle 1841), but differentiated from it by the presence of a moderately large number of small ocellated blue spots, a low number of medium-sized ocellated blue spots, a high number of dark speckles, a few dark spots, a conspicuous occipital mark and by the absence of large ocellated blue spots (PavanKumar et al., 2018). It could be added here that Neotrygon kuhlii is now considered to be endemic to Solomon Island.

\section{Taeniura meyeni Müller \& Henle, 1841 (Round} ribbon tail ray)

Taeniura meyeni Müller \& Henle, 1841, Syst. Beschr. Plagiost.: 172, [Pl. 55] (Type Locality: Mauritius).

Diagnosis: Disc is almost rounded; the buccal cavity is with 4 or 5 papillae; tooth rows are about 40 in each jaw; dorsal and caudal fins are absent; tail is stout with a large sharp spine on the dorsal surface and with a conspicuous ventral cutaneous fold; dorsal surface of the disc is rough with widely distributed granulations. The surface of the disc is grey, mottled with black spots and blotches of irregular size; the ventral fold of the tail is black (Fig. 1).

Table 1 List of new species records from Lakshadweep reefs. The status (yes/no) of previous reports of these speceis, from Andaman and Nicobar Islands and the mainland coast of India, is also shown

\begin{tabular}{llll}
\hline SI & Species & Previous records & \\
\cline { 3 - 4 } & & Andaman Nicobar Islands & Mainland Coast of India \\
\hline 1 & Neotrygon indica Pavan-Kumar et al., 2018 & Yes & Yes \\
2 & Taeniura meyeni Müller \& Henle, 1841 & Yes & Yes \\
3 & Sebastapistes cyanostigma (Bleeker, 1856) & No & No \\
4 & Pseudanthias ignitus (Randall \& Lubbock, 1981) & Yes & No \\
5 & Zoramia virdiventer Greenfield, Langston \& Randall, 2005 & No & Yes \\
6 & Lutjanus rivulatus (Cuvier, 1828) & Yes & No \\
7 & Monotaxis heterodon (Bleeker, 1854) & Yes & Yes \\
8 & Parapercis millepunctata (Gunther, 1860) & Yes & No \\
9 & Helcogramma striata Hansen, 1986 & Yes & No \\
10 & Ecsenius yaeyamaensis (Aoyagi, 1954) & No & No \\
11 & Thalassoma amblycephalum (Bleeker, 1856) & Yes & No \\
12 & Nemateleotris magnificus (Fowler, 1938) & Yes & No \\
13 & Ctenochaetus truncatus Randall \& Clements 2001 & Yes & No \\
14 & Naso hexacanthus (Bleeker 1855) & Yes & No \\
15 & Naso tonganus (Valenciennes, 1835) & & No
\end{tabular}


Distribution: Indo-West Pacific - from the Red Sea, east coast of Africa east to the Marquesas Islands, north to southern Japan and Ogasawara Islands, south to Queensland (Australia). Usually found on sandy clays adjacent to coral reefs.

Remarks: This is also a widely distributed species, however, the present report is its first record from the Lakshadweep sea.
3. Sebastapistes cyanostigma (Bleeker, 1856) (Yellow-spotted scorpionfish)

Scorpaena cyanostigma Bleeker, 1856, Natuurk. Tijdschr. Ned. Indië, 11 (2): 400 (Type locality: Kajeli, Buru, Molucca Islands, Indonesia).

Sebastapistes cyanostigma: Allen \& Erdmann, 2012, Reef Fishes of East Indies, 1: 237.

\section{Plate I}
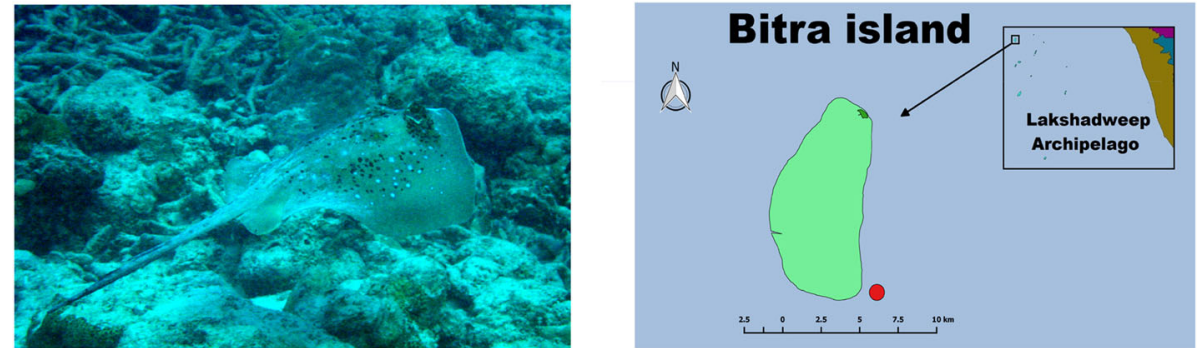

Neotrygon kuhlii (Muller \& Henle, 1841)
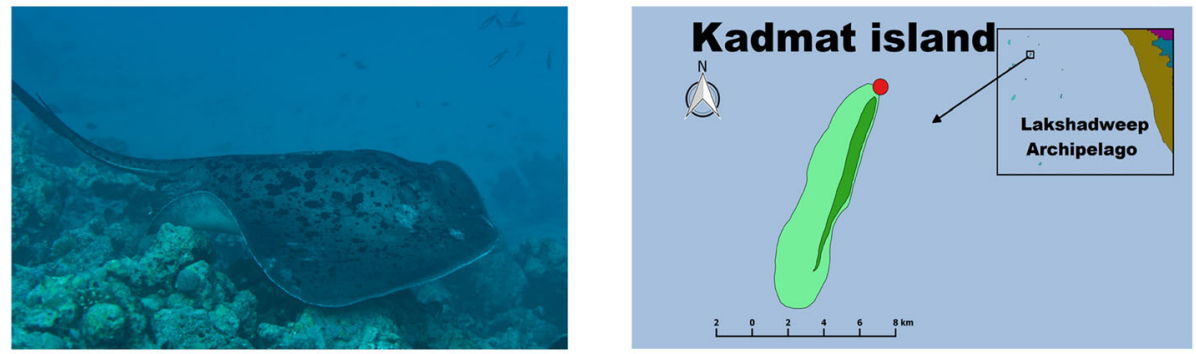

Taeniura meyeni Muller \& Henle, 1841
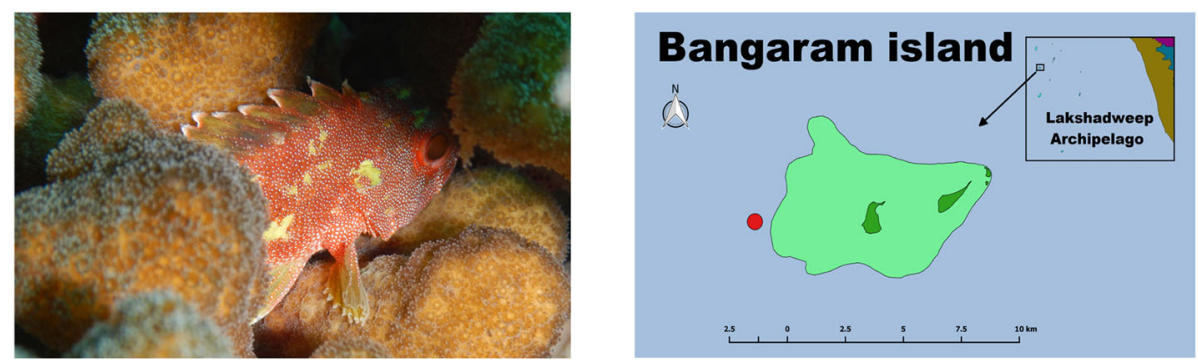

Sebastapistes cyanostigma (Bleeker, 1856)
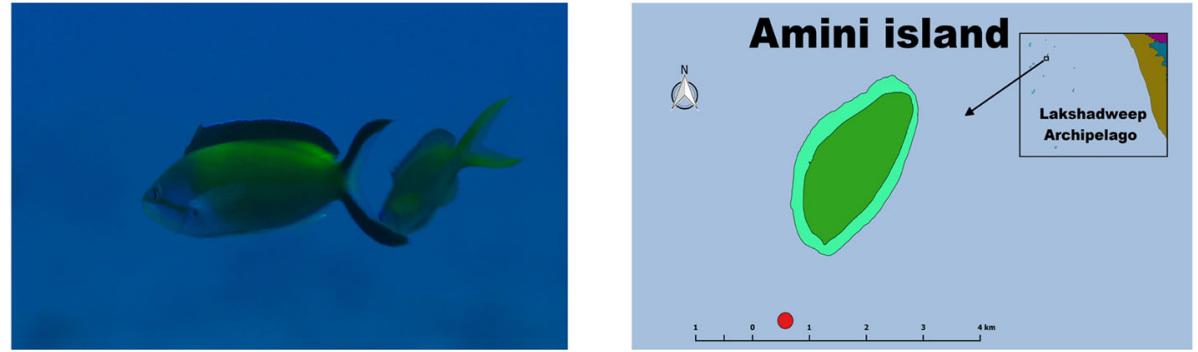

Pseudanthias ignitus (Randall \& Lubbock, 1981)

Fig. 1 New species records (Nos. 1-4) along with the site locations at which photographed 


\section{Plate II}
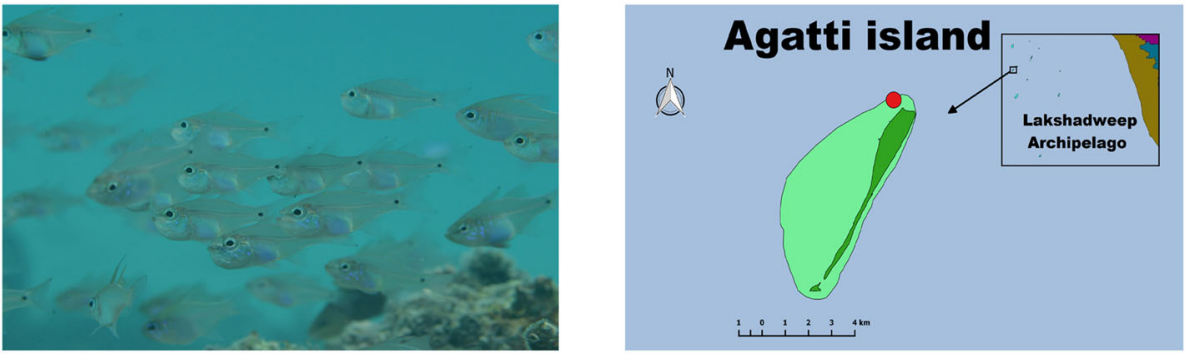

Zoramia virdiventer Greenfield, Langston \& Randall, 2005
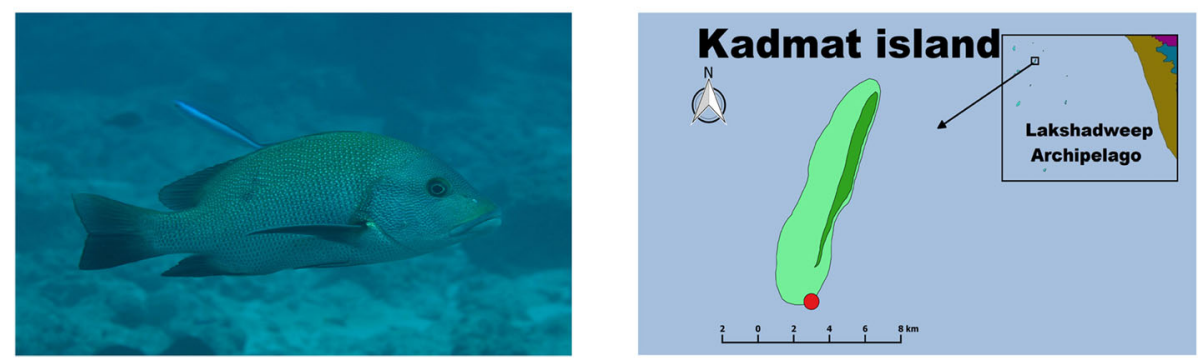

Lutjanus rivulatus (Cuvier, 1828)
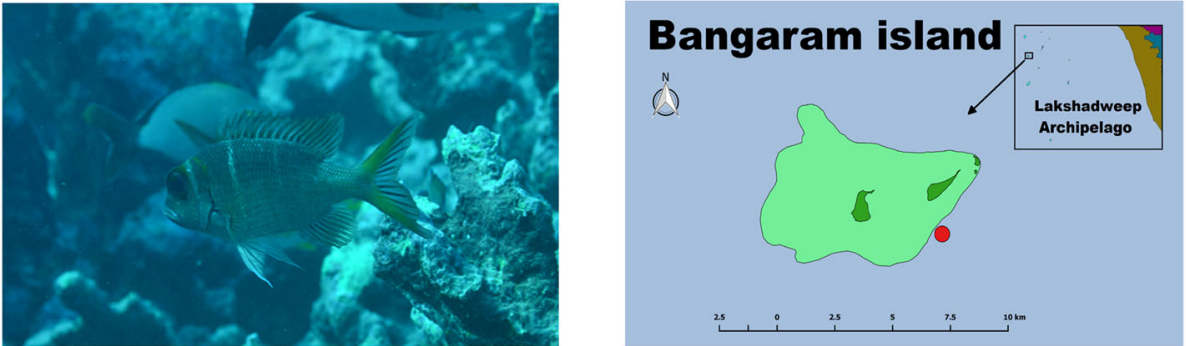

Monotaxis heterodon (Bleeker, 1854)
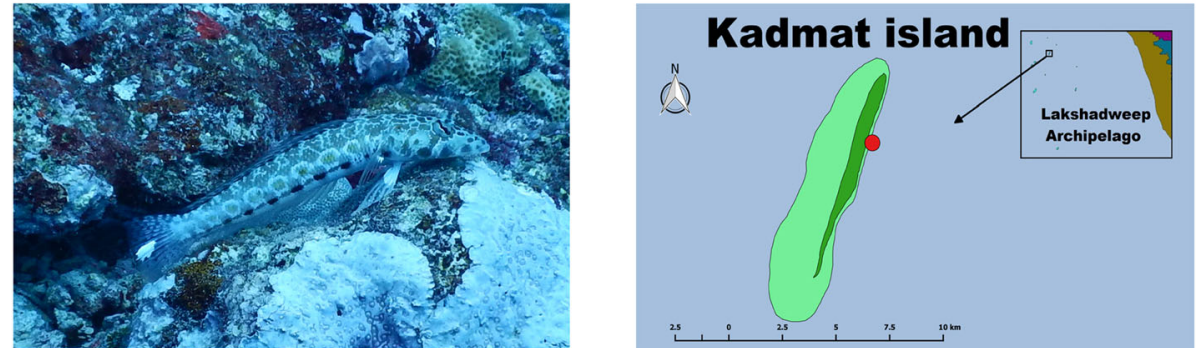

Parapercis millepunctata (Gunther, 1860)

Fig. 2 New species records (Nos. 4-8) along with the site locations at which photographed

Diagnosis: D XII, 9; A III, 5-6; P 15-16; LSS 42-45. Scales ctenoid; two suborbital ridges ending with the blunt spine; lacrimal spines five, three of which extending ventrally over upper lip; body depth about $2.7-2.8$ in SL. The body pink to reddish in colour with numerous small white spots and yellow blotches; fins yellowish (Fig. 1).
Distribution: Indo-west Pacific - the Red Sea to East Africa to the Line Islands and Samoa, Australia (Queensland and the Timor Sea) in the south to Ryukyu and Ogasawara Islands in the north. Found as solitary or in small groups among branches of Pocillopora corals in surge-affected shallow reefs. 


\section{Plate III}
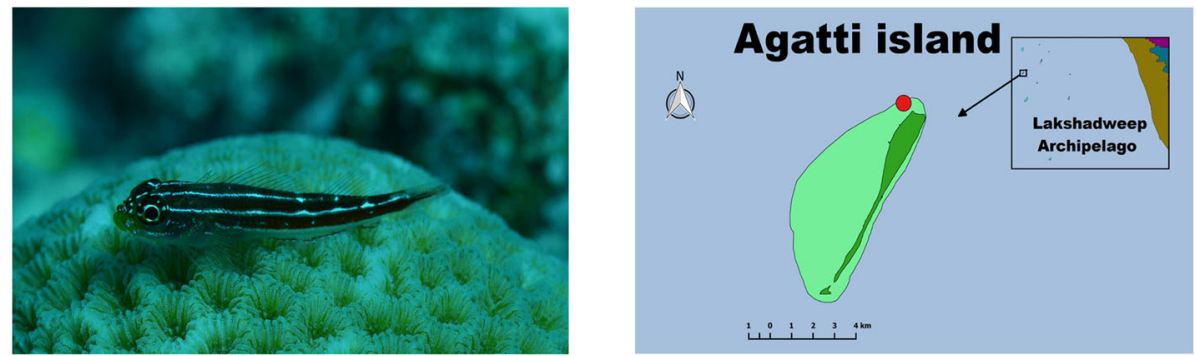

Helcogramma striata Hansen, 1986
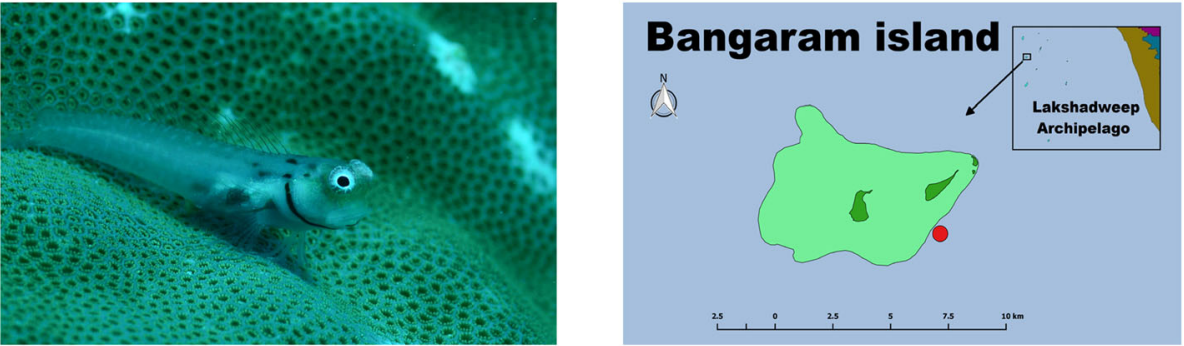

Ecsenius yaeyamaensis (Aoyagi, 1954)
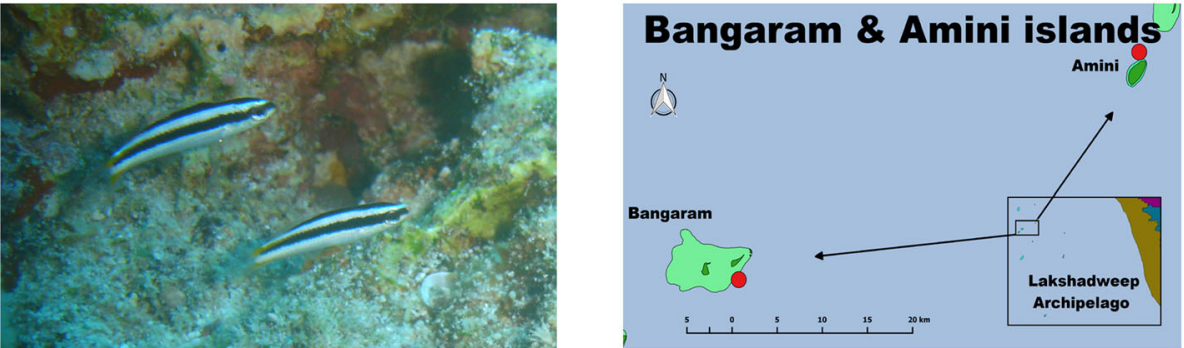

Thalassoma amblycephalum (Bleeker, 1856)
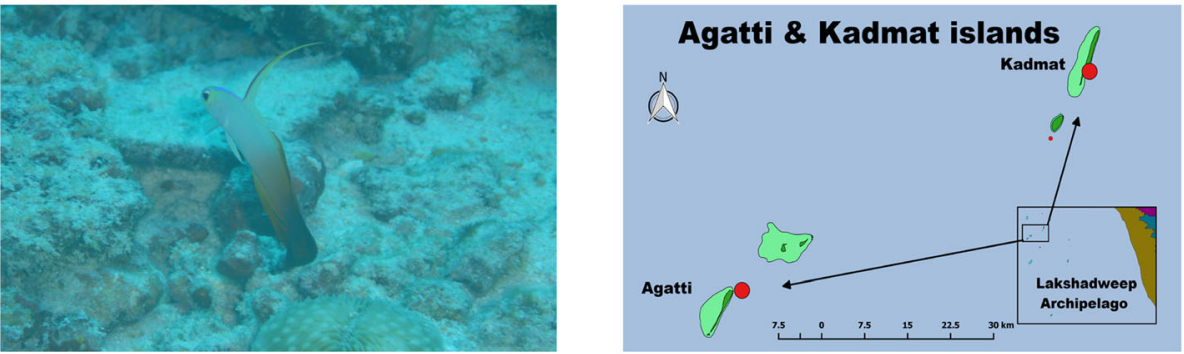

Nemateleotris magnifica Fowler, 1938

Fig. 3 New species records (Nos. 9-12) along with the site locations at which photographed

Remarks: Although widely distributed, the present report from Lakshadweep is its first record from Indian waters.

4. Pseudanthias ignitus (Randall \& Lubbock, 1981) (Flame anthias)

Anthias (Mirolabrichthys) ignitus Randall \& Lubbock, 1981, Contrib. Sci. (Los Angeles), 333: 18, Fig. 12 (Type locality: Lagoon reef, Villingili Island, North Male Atoll, Maldives).

Pseudanthias ignitus: Allen \& Erdmann, 2012, Reef Fishes of East Indies, 1: 296.

Diagnosis: DX, 16-17; A III, 7; P 19-20; LL 53-58; GR 11-12 + 22-25; body depth $2.5-3.0$ in SL; caudal fin lunate, lobes filamentous; pelvic fin with elongate filament in males. The body is usually orange in color, a lavender 


\section{Plate IV}
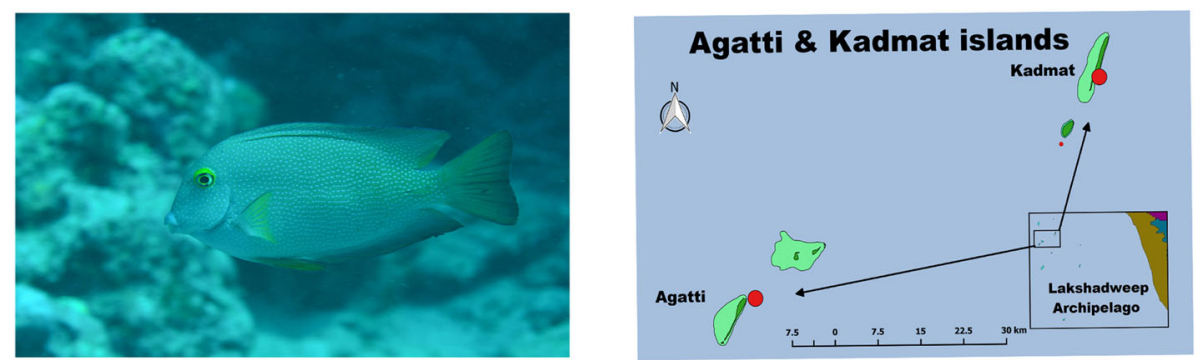

Ctenochaetus truncatus Randall \& Clements 2001
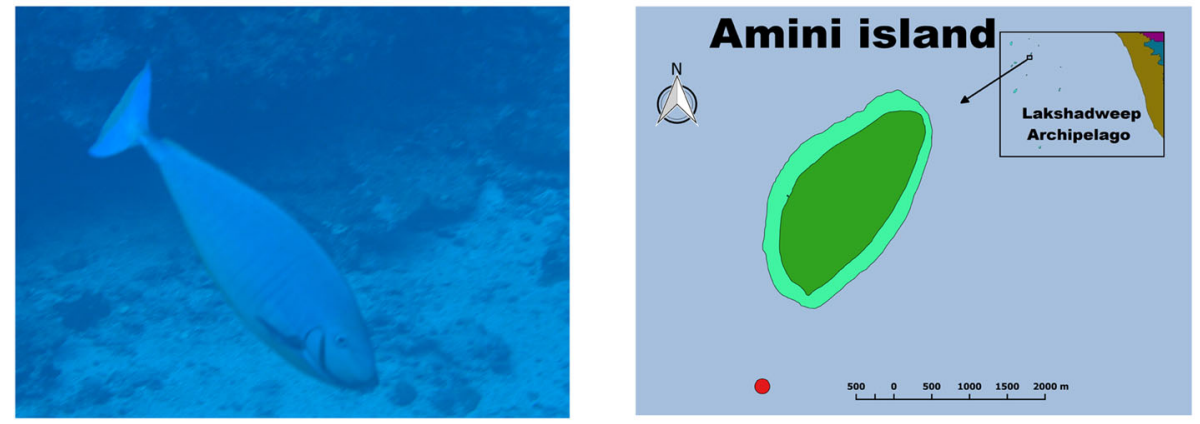

Naso hexacanthus Bleeker, 1855
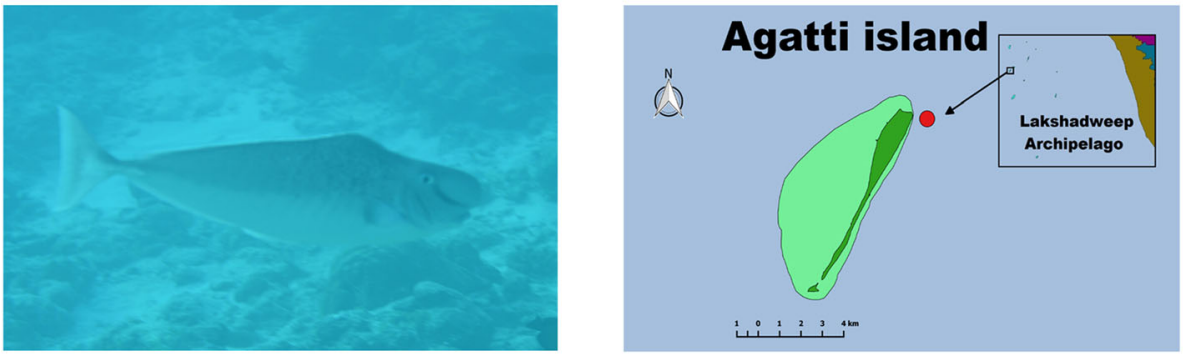

Naso tonganus (Valenciennes, 1835)

Fig. 4 New species records (Nos. 13-15) along with the site locations at which photographed

margined orange band arises from the snout to the opercle margin, the dorsal fin is red with a yellow posterior base, caudal fin is yellowish with a broad pinkish band along the upper and lower margin (Fig. 1).

Distribution: Indian Ocean - Maldives, Andaman Sea, and north-western Sumatra. Found in lagoonal reefs and the upper edge of steep slopes in shallow water.

Remarks: This species was earlier recorded from the Andaman Islands in Indian waters. Its first description from the Maldives may be an indicator of its occurrence in oceanic islands.

\section{Zoramia virdiventer Greenfield, Langston \& Randall, 2005 (Fragile cardinalfish)}

Zoramia virdiventer Greenfield, Langston \& Randall, 2005, Proc. California Acad. Sci., 56 (33): 631, Figs. 1E,
4-6 (Type locality: Lagoon side of Pig Island (Tab Island), Madang Province, Papua New Guinea).

Diagnosis: D VI + I, 9; A-II, 9; P 14; LL 24; GR 6$7+24-27$; body depth $2.5-3.3$ in SL; second dorsal fin spine $19.0-21.5 \% \mathrm{SL}$; anal fin spine $13.0-16.0 \%$ SL. The body color is semi-transparent with silvery reflections anteriorly on the abdomen and operculum; head and anterior part of the body is with scattered blue spots; sometimes a faint blackish band on the sides of snout; a distinct small black spot is found at the middle of caudal fin base, about half of the pupil or more in size; the tip of caudal fin lobes are often black (Fig. 2).

Distribution: Indo-Pacific: Indonesia east to Samoa, Fiji and Marshal Island, north to Japan south to Australia. It is usually found in sheltered reefs in shallow water up to the depth of $15 \mathrm{~m}$. 
Remarks: The present report forms its first report from Indian waters, extending its distributional range westward to the Arabian Sea from the earlier known western boundary, Indonesia.

\section{Lutjanus rivulatus (Cuvier, 1828) (Blubberlip snapper)}

Diacope rivulata Cuvier, in Cuvier \& Valenciennes, 1828, Hist. nat. pois., 2: 414, Pl. 38 (Type locality: Red Sea; Java, Indonesia; Puducherry, India; [Malabar] India, Arabian Sea, western Indian Ocean).

Lutjanus rivulatus: Allen \& Erdmann, 2012, Reef Fishes of East Indies, 2: 453.

Diagnosis: D X, 15; A III, 8 P 17; V I., 5; LL 47-49. Body deep, dorsal profile of head steeply sloped; vomerine tooth patch is crescentic; the posterior profile of anal fin pointed; preopercular notch moderately developed. Body reddish-brown; each scale is with one or two bluish spots; head with fine wavy blue lines; lips whitish; all fins are yellow in color with dusky markings; the caudal fin is grayish with yellow margin (Fig. 2).

Distribution: Indo-Pacific - Red Sea, to the east coast of Africa, through India to Japan and Australia to Tahiti Island. Found in inshore reef areas.

Remarks: It is a commonly occurring species along Indian coastal waters, however, been recorded for the first time from Lakshadweep Islands.

\section{Monotaxis heterodon (Bleeker, 1854) (Redfin emperor)}

Pagrus heterodon Bleeker, 1854, Natuurk. Tijdschr. Ned. Indië, 6 (1): 54 (Type locality: Sindangole, Halmahera, Indonesia).

Monotaxis heterodon: Allen \& Erdmann, 2012, Reef Fishes of East Indies, 2: 502.

Diagnosis: D X, 10; A III, 9; P 13-14; LL 44-47; Ltr 5/ 12.5; Small scales are present on the inner surface of the pectoral fin axil; the jaw is with 5-7 large molariform teeth on sides; body depth 2.2 in SL; eyes are large, 2.73.8 in head length. The adults are silvery grey with narrow dark scale margins; pectoral axil is with a black blotch; three or four narrow white bars of 1-2 scales wide, appear on the upper part of the body; each lobe of the caudal fin has an orange band; fins yellowish or reddish (Fig. 2).

Distribution: Indo west-Pacific - Seychelles, Maldives, Sri Lanka, and Andaman Islands of India, Indonesia, Malaysia, Papua New Guinea, Great Barrier Reef, Marshall Islands, and New Caledonia. Found in coral reefs in shallow water as solitary or in small groups. This is the first report of this species from Lakshadweep Islands.
Remarks: This species is very closely similar to Monataxis grandoculis, which is often recorded from Lakshadweep. However, pale bars on back 3-4 scale wide and scale rows between lateral line and anal fin origin 13.5, differentiates from $M$. grandoculis.

\section{Parapercis millepunctata (Gunther, 1860)} (Blackdotted sandperch)

Percis millepunctata Günther, 1860, Catalog. Fish. British Mus., 2: 241 (Type locality: Sri Lanka).

Parapercis millepunctata: Allen \& Erdmann, 2012, Reef Fishes of East Indies, 2: 756.

Diagnosis: D IV, 20-21; A I, 17-18; P 17; GR 1417; LL 55-60; predorsal scales 9-11; six canines are present at the front of lower jaw; the last spine of the dorsal-fin is joined with first dorsal soft ray at the level of spine tip. Dark and light brown spots are noted on the back; the lower half white with two rows of spots, where the upper row is rounded and lower row elongate; the upper row of the spots is ocellated in males, while females are with a smaller dark brown spot at this position; middle of the caudal fin is with a white streak (Fig. 2).

Distribution: Indo-Pacific- the Maldives, Sri Lanka to the Pitcairn group of islands, north to the Ryukyu (Japan) and Ogasawara islands, south to the southern Great Barrier Reef (Australia) and New Caledonia. It occurs in sand-rubble bottoms near reefs in shallow water.

Remarks: This is the first report of this species from Lakshadweep islands, though it has been reported in the Indo-Pacific including the Andaman Islands.

\section{Helcogramma striata Hansen, 1986 (Tropical striped triplefin)}

Helcogramma striata Hansen, 1986, Bulletin of Marine Science, 38 (2): 349, Fig. 18 (Type locality: Toga Point rocks, Miyakejima, Izu Islands, Japan).

Diagnosis: D III + XI-XV + 9-12; A I, 17-22; P 15-17; V I, 2; LL pored 14-20, continuous; LSS 38-39; head scaled on nape, belly naked; mandibular pores $3+2+3$; one free pterygiophore is found between the second and third dorsal fins. Upper two-thirds of the body red with three continuous white or bluish-white stripes, 6-7 spots are observed between the lowermost two stripes; eyes are with a yellow ring (Fig. 3).

Distribution: Indo-west Pacific - from Sri Lanka, eastward to the Andaman Sea, to Line Islands, Fiji, and Australia (Western Australia and Queensland) in the south to Taiwan, Japan, and Ogasawara Islands in the north.

Remarks: The present record extends its distributional range further westward to Lakshadweep Islands. Holleman (2007) reviewed the genus Helcogramma 
and stated the occurrence of $H$. striata from Sri Lanka and eastwards. This species is closely similar to $H$. maldivensis Fricke and Randall, which has broken longitudinal stripes, naked nape, and lesser lateral scales (36-37).

\section{Ecsenius yaeyamaensis (Aoyagi, 1954) (Yaeyama blenny)}

Salarias yaeyamaensis Aoyagi, 1954, Zoological Magazine Tokyo [Dobutsugaku Zasshi], 63 (5): 213, Figs. 2-3 (Type locality: Iriomote Island, Okinawa Prefecture, Ryukyu Islands, Japan).

Ecsenius yaeyamaensis: Allen \& Erdmann, 2012, Reef Fishes of East Indies, 2: 821.

Diagnosis: D XI-XII, 13-15; A-II, 14-17; V I, 3; lateralline tubes reach up to below the 10th or 11th dorsal-fin spine; nasal cirri are present on the posterior rim of anterior nostril; the body depth at anal-fin origin is 5.3-5.7 in SL: The body is light brown at the abdomen, and the cheek is pale whitish; the interrupted dark stripe is found behind the eye; lower margin of the cheek is black; the base of the pectoral-fin base is with a Y-shaped mark, sometimes with white spots and blotches on the side (Fig. 3).

Distribution: Indo-West Pacific: Sri Lanka to Vanuatu, north to southern Japan, south to Australia and New Caledonia. Found in sheltered and coastal reefs in shallow water, solitary or in small groups.

Remarks: The present report is the first record from Indian waters and extends its distributional range westward to the Lakshadweep Sea, from the earlier known western boundary, Sri Lanka.

\section{Thalassoma amblycephalum (Bleeker, 1856)} (Bluntheaded Wrasse)

Thalasoma amblycephalum Bleeker, 1856, Natuurk. Tijdschr. Ned. Indië, 11 (2): 400 (Type locality: Kajeli, Buru, Molucca Islands, Indonesia).

Diagnosis: Dorsal rays VIII, 13; Anal rays III, 11: pectoral rays 15; lateral line scales $26-27$; jaws with one pair of canine teeth anteriorly. The caudal fin is truncate to slightly emarginate. Becoming lunate in large males. Attains to $15 \mathrm{~cm}$. Male reddish with vertical green lines, yellowish zone on the nape, green head with pair of pink lines, and yellow pectoral fins with a large blue spot on the outer portion. Female pale greenish on the back with broad dark brown, mid-lateral stripe, and white on the lower half. Occurs in aggregations over shallow reefs, the upper edge of the lagoon, and seaward areas (Fig. 3).

Distribution: Indo-Pacific. This is the first report of this species from Lakshadweep islands, though it has been known from the Andaman Islands.

\section{Nemateleotris magnificus (Fowler, 1938) (Fire goby)}

Nemateleotris magnificus Fowler, 1938, Proc. U. S. Nat. Mus., 85 (3032): 132 (Type locality: Buka Buka Island, Gulf of Tomini, Sulawesi, Indonesia).

Diagnosis: D VI + I, 28-32; A I, 27-30; P 19-20; V I, 5; GR 5-6 + 17-19; LSS 110-130; body depth - 4.4-4.9 in SL; first dorsal fin elongate, and when appressed reaches beyond one-third of the second dorsal fin base; posterior body scales are with 12 or more ctenii. The anterior body is pale grey to whitish in color; snout yellow; posterior part of the body is red in color; dorsal pennant is pale yellow (Fig. 3).

Distribution: Widely distributed in Indo-Pacific - from East Africa to the Hawaiian, Marquesan, and Pitcairn islands, north to the Ryukyu Islands, south to New Caledonia and the Austral Islands. Found in outer reef slopes in shallow water.

Remarks: This species was earlier known from Andamans in Indian waters and the present report is its first record from Lakshadweep.

\section{Ctenochaetus truncatus Randall \& Clements 2001 (Indian gold-ring bristle-tooth)}

Ctenochaetus truncatus Randall \& Clements 2001, Indo-Pacific Fishes, No. 32: 25, Pls. 3C, 6 F-H (Type locality: Off point just north of the main settlement, La Digue, Seychelles).

Diagnosis: D VIII, 25-27; A III, 23-25; P 15-16 (rarely 17); body depth - 1.8-2.1 in SL; The teeth are movable with expanded incurved tips which bear only lateral denticulations (fewer than 5); the posterior dorsal soft rays are longer than anterior; a single folding antrorse spine is on each side of the caudal peduncle, in a well-defined deep groove; caudal fin truncate to lunate, its concavity at most 16.5 in SL. The body is with numerous small blue to yellow spots in life; the edge of the orbit is with a partial or complete yellow rim; the color is young bright yellow (Fig. 4).

Distribution: Widely distributed in the Indian Ocean: South Africa, East Africa, Mozambique Channel, Aldabra, Madagascar, and Mascarenes, east to the Andaman Sea, Indonesia, Christmas Island, and Cocos Keeling Islands. Found in sheltered lagoon and outer reef slopes.

Remarks: This is the first report of this species from Lakshadweep islands, though it has been known from the Andaman Islands.

\section{Naso hexacanthus (Bleeker 1855) (Sleek} unicornfish) 
Priodon hexacanthus Bleeker, 1855, Natuurk. Tijdschr. Ned. Indië, 8 (3): 421 (Type Locality: Ambon Island, Molucca Islands, Indonesia).

Naso hexacanthus: Allen \& Erdmann, 2012, Reef Fishes of East Indies, 3: 1031.

Diagnosis: D V-VII (usually VI), 26-29; A-II, 27-30; P 17-18; V I, 3; body depth 2.6-3.0 in SL; The top of the head is without any protuberance or horn; a short groove is found in front of the eye; a pair of bony plates are present on the caudal peduncle, which develops into a knife-like keel in large adults; the caudal fin is emarginate in young. The body is brown or bluish-grey to pale blue, shading to yellowish towards ventral half; cheek and opercle are margined black or yellowishbrown (Fig. 4).

Distribution: Indo-Pacific: the Red Sea and East Africa, Mozambique Channel, Seychelles, including the Mascarene Islands to the Hawaiian, Marquesas, and Ducie islands (Pitcairn Group), north to southern Japan and Ogasawara Islands, south to Lord Howe Island and New Caledonia and Clipperton Island in Eastern Pacific.

Remarks: This report forms the first record of this species from Lakshadweep islands, thus confirming its' listing by Arthur (2004). This species has been known from Andaman Islands.

\section{Naso tonganus (Valenciennes, 1835) (Bulbnose} unicorn fish)

Naseus tonganus Valenciennes (ex Quoy \& Gaimard), in Cuvier \& Valenciennes, 1835, Hist. nat. poiss., 10: 292 (Type locality: Tongatapu, Tonga Islands, South Pacific).

Naso tonganus: Allen \& Erdmann, 2012, Reef Fishes of East Indies, 3: 1034.

Diagnosis: D V, 27-30; A-II, 26-28; P 16-18; V I, 3; body depth $2.2-3.0$ in SL; The adults are with a bulbous protuberance on the front of the head extending well beyond the snout tip in large adults; there is a hump on the back; a pair of bony plates is present posteriorly on each side of the caudal peduncle. The body is gray in color; the head and dorsal parts are scattered with numerous small black spots, which are concentrated below the hump in large adults; ventral half of the body is pale gray to white; broad black submarginal bands are found on the pectoral fins, which become prominent on the underside of the fin (Fig. 4).

Distribution: Indo-West Pacific: East Africa to the Samoan Islands, Australia in the south, the Ryukyu Islands in the north. This report forms the first record of this species from Indian waters.

Remarks: This species was earlier confused with Naso tuberosus in the western Indian Ocean and probably in Lakshadweep. Johnson (2002) reviewed the Naso tuberosus complex and distinguished $N$. tonganus from $N$. tuberosus. $N$. tonganus may be distinguished from $N$. tuberosus by the more expanded and bulbous snout, which may extend anteriorly well beyond the tip of the upper lip in adults and a prominent hump on the back, apart from the other characters explained in Johnson (2002).

Inclusive of the 15 new records, a total of 856 species of fishes under 432 genera belonging to 145 families and 43 orders are now known from Lakshadweep waters. These numbers, however, are not validated to be the present or existing species richness in these habitats, as the species recorded through the rapid survey are mere $1 / 10$ of the total species records for this region. We suggest extensive surveys for gathering up-to-date species richness data.

The checklist presented here shows that a total of 422 species (49.3\%) belong to just 14 families, represented by 15 or more species in each (Table 2). The remainder 131 families contain 15 or lesser number of species, where 18 families are with two species each and 56 families with just one species. The family Labridae is represented by a maximum number of genera (24), followed by Apogonidae (17), Gobiidae (16), Carangidae (15), Pomacentridae, and Blenniidae (14 each). The butterflyfish genus Chaetodon is the most diverse with 22 species, followed by grouper genus Epinephelus (21 species) and snapper genus Lutjanus (17 species). The most commercially significant fish families are Scombridae (14 spp.), Serranidae (30 spp. of 45 spp. known), Lethrinidae (17 spp.), Lutjanidae (21 spp.),

Table 2 Major species-rich fish families recorded in Lakshadweep Islands

\begin{tabular}{llll}
\hline Family & Genera & Species & \% of species richness \\
\hline 1. Labridae & 24 & 59 & 6.9 \\
2. Pomacentridae & 14 & 52 & 6.1 \\
3. Serranidae & 11 & 45 & 5.3 \\
4. Apogonidae & 17 & 32 & 3.7 \\
5. Carangidae & 15 & 31 & 3.6 \\
6. Chaetodontidae & 04 & 31 & 3.6 \\
7. Acanthuridae & 05 & 27 & 3.3 \\
8. Muraenidae & 07 & 25 & 2.9 \\
9. Blenniidae & 14 & 23 & 2.7 \\
10. Gobiidae & 16 & 22 & 2.6 \\
11. Scaridae & 07 & 21 & 2.5 \\
12. Lutjanidae & 04 & 21 & 2.5 \\
13. Lethrinidae & 04 & 17 & 2.0 \\
14. Scorpaenidae & 09 & 16 & 1.9 \\
Subtotal $\mathbf{1 4}$ & $\mathbf{1 5 1}$ & $\mathbf{4 2 2}$ & $\mathbf{4 9 . 3}$ \\
Others $\mathbf{1 3 1}$ & $\mathbf{2 8 1}$ & $\mathbf{4 3 4}$ & $\mathbf{5 0 . 7}$ \\
Total $\mathbf{1 4 5}$ & $\mathbf{4 3 2}$ & $\mathbf{8 5 6}$ & $\mathbf{1 0 0 . 0}$ \\
\hline
\end{tabular}


Carangidae (31 spp.), Mullidae (15 spp.), Sphyraenidae (9 spp.), Belonidae (7 spp.), Istiophoridae (4 spp.), Polynemidae (4 spp.), Coryphaenidae and Xiphiidae (1 sp. each), that combinedly form about $18 \%$ ( 154 species) of the total fish known from Lakshadweep. The 16 species of freshwater fishes reported in the waterbodies in these islands are known to be introduced, representing families Cyprinidae, Characidae, Clariidae, Osphronemidae, Cichlidae, Aplocheilidae, and Poeciliidae (Sirajudheen and Khan 2014), with the species Gambusia affinis and Poecilia reticulata most commonly reported.

\section{Conclusion}

The authors could collect photographic evidence of the 15 species of fishes as new records for the Lakshadweep archipelago within the short period of the survey, suggesting that extensive fish surveys in these waters could add many more species to the present tally from these islands. The authors also observe the need for an up-todate inventory of species richness in this region. The new records presented in this work, too, are known from the Maldives, and Sri Lanka, indicate the zoogeographical affinity of these regions.

\section{Abbreviations}

D: Dorsal fin; A: Anal fin; P: Pectoral fin; V: Pelvic fin; GR: Gill rakers; LL: Lateral line scales; LSS: Lateral scale series; Ltr: Lateral transverse scales; SL: Standard length

\section{Supplementary Information}

The online version contains supplementary material available at https://doi. org/10.1186/s41200-021-00208-6.

Additional file 1. Appendix I.

Additional file 2. Appendix 11 .

Additional file 3. Supplementary material S1.

\section{Acknowledgements}

The authors thank Dr. Kailash Chandra. Director, Zoological Survey of India, for the approval to undertake this study and the support to bring out this publication. The authors also thank the assistance of Dr. K. Paramasivam, Mr. Riyaz, and Mr. Sharaffudin during the field survey.

\section{Authors' contributions}

RR, ARCN, and SS participated in the Lakshadweep field survey, collected photographs of fishes, and developed the concept for this manuscript. RPT and MSS confirmed the identification of the new species records and finalized the checklist. SC compiled the preliminary checklist. RR and DAT edited the manuscript. All authors read and approved the final manuscript.

\section{Funding}

The funding for the field survey and logistics were provided from the budget grant allotted for executing the sanctioned annual programmes of research of the Marine Biology Regional Centre, Zoological Survey of India. The funding for this manuscript's preparation and publication is sourced from the sanctioned funds under the project 'Conservation Management of coral reefs in Lakshadweep - Long-term coral reef monitoring Programme' funded by the Department of Environment and Forests, Lakshadweep.

\section{Availability of data and materials}

All data generated or analysed during this study are included in this published article [and its supplementary information files].

\section{Declarations}

Ethics approval and consent to participate

Not Applicable.

\section{Consent for publication}

Not Applicable.

\section{Competing interests}

The authors declare that they have no competing interests.

\section{Author details}

${ }^{1}$ Marine Biology Regional Centre, Zoological Survey of India, Chennai 600028 India. ${ }^{2}$ Andaman \& Nicobar Regional Centre, Zoological Survey of India, Port Blair, U. T. of Andaman Nicobar Islands 744102, India. ${ }^{3}$ Marine Fish Section, Zoological Survey of India, Kolkata 700053, India. ${ }^{4}$ Department of Environment and Forests, Kavaratti, U. T. of Lakshadweep 682555, India.

Received: 6 January 2020 Accepted: 7 May 2021

Published online: 25 June 2021

\section{References}

Abdussamad EM, Retheesh TB, Thangaraja R, Bineesh KK, Prakasan D. Sphyraena arabiansis a new species of barracuda (family: Sphyraenidae) from the southwest coast of India. Indian J Fish. 2015:62:1-6.

Ajithkumar TT, Vinoth R, Prakash S, Balasubramanian T. Reef fishes of the Lakshadweep archipelago. Centre for Advanced Study in Marine Biology, Annamalai University, Parangipettai; 2012.

Alcock AW. Natural history notes from H.M. Indian marine survey steame 'Investigator'. No. 18. On the bathybial fishes of the Arabian Sea, obtained during the season 1889-1890. Ann Mag Nat Hist. 1890;6(34):295-311. https:// doi.org/10.1080/00222939008694038.

Alcock AW. Class Pisces. Natural history notes from H.M. Indian marine survey steamer 'Investigator'. Series II., No. 1. On the results of deep-sea dredging during the season 1890-91. Ann Mag Nat Hist. 1891;8(16-34):119-38 Pls. 7-8.

Alcock AW. Natural history notes from H.M. Indian marine survey steamer 'Investigator'. Series II, No. 5. On the bathybial fishes collected during the season of 1891-92. Ann Mag Nat Hist. 1892:10:345-65 PI. 18.

Alcock AW. Natural history notes from H.M. Indian marine survey steamer 'Investigator', Commander C.F. Oldham, R.N., commanding. Series II., No. 11. An account of a recent collection of bathybial fishes from the Bay of Bengal and from the Laccadive Sea. J Asiat Soc Bengal. 1894:63:115-37 Pls. 6-7.

Alcock AW. Natural history notes from H.M. Indian marine survey steamer 'Investigator'. Series II. No. 23. A supplementary list of the marine fishes of India, with descriptions of two new genera and eight new species. J Asiat Soc Bengal. 1896;65:301-38.

Anand VPE, Pillai NGK. Habitat distribution and species diversity of coral reef fishes in the reef slope of the Kavaratti atoll, Lakshadweep, India. Mar Biol Ass India. 2002;45:88-98.

Anand VPE, Pillai NGK. Community organization of coral reef fishes in the rubble sub-habitat of Kavaratti atoll, Lakshadweep, India. Mar Biol Ass India. 2005:47: $77-82$

Anand VPE, Pillai NGK. Coral reef fish abundance and diversity of seagrass beds in Kavaratti atoll, Lakshadweep, India. Indian J Fish. 2007;54:11-20.

Aneeshkumar KV, Khanolkar SP, Pravin P, Meenakumari B, Radhakrishnan EV. First record of the pelagic thresher shark Alopias pelagicus (Pisces: Alopiiformes: Alopiidae) from the Lakshadweep Sea, India. Mar Biodiv Rec. 2012;5. https:// doi.org/10.1017/S175526721100111.

Aneeshkumar KV, Khanolkar SP, Pravin P, Meenakumari B, Radhakrishnan EV. First record of the Grey reef shark Carcharhinus amblyrhynchos (Bleeker, 1856) (Carcharhiniformes: Carcharhinidae) from the Lakshadweep Sea, India. J Threatened Taxa. 2013:5:3580-2.

Aneeshkumar KV, Pravin P, Meenakumari B, Khanolkar PS, Biju MV. Shark bycatch in the experimental tuna longline fishery in Lakshadweep Sea, India. J Appl Ichthyol. 2015;31:301-7. 
Arthur R. Patterns and processes of reef recovery and human resource use in the Lakshadweep Islands, Indian Ocean, Ph.D. Thesis, James Cook University; 2004.

Ayyangar SR. Notes on the fauna and fishing industries of the Laccadives. Madras Fish Bull. 1922;15:45-69.

Bahuguna A, Naik SR. Coral mapping of India. Scientific Note. SAC/RAS/RASG/ DOD $\neg C O S / S N / 07 / 94$, Space Application Center, Ahmedabad, India; 1994.

Balachandran K, Abdul NM. A checklist of fishes of the Exclusive Economic Zone of India collected during the research cruises of FORV Sagar Sampada. Proc. First Workshop Scient. Result. FORV Sagar Sampada; 1989. p. 305-24.

Balan V. Notes on a visit to certain islands of the Laccadive archipelago, with special reference to fisheries. J Bombay Nat Hist Soc. 1958;55(2):297-306.

Barman RP, Saren SC, Mishra SS. On the occurrence of Lutjanus vitta (Quoy\&Gaimard, 1828) (Pisces: Perciformes: Lutjanidae) from Lakshadweep, India. Rec Zool Surv India. 2014;114:189-90.

Burton RW. A visit to the Laccadive Islands. J Bombay Nat Hist Soc. 1940;41:489-513.

Caeiro S. Coral Fauna of Lakshadweep with Special Reference to Agatti Atoll. Doctoral dissertation, Goa University; 1999.

Ellis RH. A short account of the Laccadive Islands and Minicoy. Madras: Govt Press; 1924

Gardiner JS. The Fauna and Geography of the Maldive and Laccadive Archipelago. Being the Account of the Work carried on and of the Collections made by an Expedition during the years 1899 and 1900. 2 vols. (8 parts). Cambridge: Cambridge University Press; 1901-1905.

Geevarghese GA, Akhil B, Magesh G, Krishnan P, Purvaja R, Ramesh R. A comprehensive geospatial assessment of seagrass distribution in India. Ocean Coast Manag. 2017. https://doi.org/10.1016/j.ocecoaman.2017.10.032

Ghosh AK. Fauna of Lakshadweep: An overview. In: Fauna of Lakshadweep. Zool Sure India, Kolkata; 1991. p. 1-5.

Gillanders BM. Seagrasses, Fish and Fisheries. Seagrasses. In: Larkum AWD, et al., editors. Biology, Ecology and Conservation; 2006. p. 503-36.

Holleman W. Fishes of the genus Helcogramma (Blennioidei: Tripterygiidae) in the Western Indian Ocean, including Sri Lanka, with descriptions of four new species. Smithiana Bull. 2007;7:51-81.

Hornell J. Report on the results of a fishery cruise along the Malabar coast and the Laccadive Islands in 1908. Madras Fish Bull. 1910;4:71-126.

Idreesbabu KK, Cernohorsky NH, Sureshkumar S. New record of five Butterflyfishes (family: Chaetodontidae) from the Lakshadweep archipelago, Western Indian Ocean, with notes on occurrence of four additional species. Int J of Fish and Aqua Stud. 2014;2:92-101.

Jianguo DU, Yanguo W, Teguh P, Jianji L, Christianus MP, Ricardo H, et al. Temporal and spatial variation of fish community and their nursery in a tropical seagrass meadow. Acta Oceanol Sin. 2018;37:63-72.

Jones S. A preliminary survey of the common tuna baitfishes of Minicoy and their distribution in the Laccadive archipelago. Proc Symp Scombroid Fishes Mar Biol Assoc India Mandapam Camp. 1964;2:643-80.

Jones S. Catalog of fishes in the Lacadive archipelago in the reference collections of the CMFR institute. Bull Cent Mar Fish Res Inst. 1969;8:1-32.

Jones S, Kumaran M. The fishing industry of Minicoy Island with special reference to the tuna fishery. Indian J Fish. 1959;6:30-57.

Jones S, Kumaran M. On the occurrence of fishes of the family Schindleriidae in the Indian Ocean. Curr Sci. 1964a;33:145.

Jones S, Kumaran M. New records of fishes from the seas around India - part I. J Mar Biol Ass India. 1964b;6:285-306.

Jones S, Kumaran M. New records of fishes from the seas around India - part II. J Mar Biol Ass India. 1965a;7:108-23.

Jones S, Kumaran M. New records of fishes from the seas around India - part III. J Mar Biol Ass India. 1965b;7:381-400.

Jones S, Kumaran M. New records of fishes from the seas around India - part IV. J Mar Biol Ass India. 1966:8:163-80.

Jones S, Kumaran M. New records of fishes from the seas around India - part V. J Mar Biol Ass India. 1967;9:1-11.

Jones S, Kumaran M. New records of fishes from the seas around India - part VI. J Mar Biol Ass India. 1968:10:321-31.

Jones S, Kumaran M. New records of fishes from the seas around India - part VII. Jar Biol Ass India. 1970;2:187-96.

Jones S, Kumaran M. Fishes of the Laccadive archipelago. The Nature Conservation and Aquatic Sciences Service, Trivandrum; 1980.

Johnson JW. Naso mcdadei, a new species of unicornfish (Perciformes: Acanthuridae), with a review of the Naso tuberosus species complex. Aust $J$ Zool. 2002;50(3):293-311.
Joshi KK, Nair RJ, Samad EMA, Thomas S, Kakati VS, Jasmine S, et al. The Carangids of India: A Monograph. Central Marine Fisheries Research Institute, Kochi; 2011.

Karkarey R. Understanding the response of groupers (epinephelidae) to climatechange and fishing disturbances in the Lakshadweep archipelago, India. Ph. D. Thesis. Manipal Academy of Higher Education; 2018.

Kelkar N, Arthur R, Marba N, Alcoverro T. Green turtle herbivory dominates the fate of seagrass primary production in the Lakshadweep islands (Indian Ocean). Mar Ecol Prog Ser. 2013;485:235-43. https://doi.org/10.3354/meps10406.

Komyakova V, Jones GP, Munday PL. Strong effects of coral species on the diversity and structure of reef fish communities: a multi-scale analysis. PLoS One. 2018;13(8):e0202206. https://doi.org/10.1371/journal.pone.0202206.

Koya SK, Kunhikoya VA, Kaladharan P. Sea grass ecosystem - a Lakshadweep perspective. Kozhikode: Central Marine Fisheries Research Institute; 2012.

Mathew MJ, Ramachandran TB. Notes on a survey of the fishing industry of the Laccadive and Amindivi Islands. In: Fisheries Station Reports and Year Book, 1954-55. Madras: Govt. Press; 1956. p. 125-37.

Murty VS. Ornamental fish resources of Lakshadweep. Geol Surv India Spl Pub. 2001;56:103-11.

Murty VS. Marine ornamental fish resources of Lakshadweep. CMFRI, Spl Pub. 2002;72:1-134.

Nair RJ, Dinesh Kumar S, Kuriakose S, Praveen P. A checklist of snappers (family: Lutjanidae) from Indian waters. J Aqua Biol Fish. 2014;2:551-5.

Nasser AKV. Length-weight relationships of tuna baitfish from Lakshadweep Islands, India. Naga ICLARM Q. 1999;22:42-4.

Nasser AKV, Sivdas M, Gopakumar G, Pillai PP. Tuna live-bait fishes - their exploitation, conservation and management in Lakshadweep. In: Pillai NGK, Menon NG, Pillai PP, Ganga U, editors. Management of Scombrid fisheries. Kochi: Central Marine Fisheries Research Institute; 2002. p. 148-54.

Nobi EP, Dilipan E, Sivakumar K, Thangaradjou T. Estimation of the aerial cover of seagrasses of Lakshadweep islands (India) using Indian remote sensing satellite (IRS P6 LISS IV). J Indian Soc Remote Sens. 2012;40(3):467-81. https:// doi.org/10.1007/s12524-011-0179-y.

Nordlund LM, Unsworth RKF, Gullström M, Cullen-Unsworth LC. Global significance of seagrass fishery activity. Fish Fish. 2017;19(3):399-412. https:// doi.org/10.1111/faf.12259.

Noushad MK, Sirajudheen TK, IdressBabu KK. Intertidal Icthyufaunal diversity of Androth Island, Lakshadweep, India- a call for developing culture-based fishery. J Aqua Biol Fish. 2014;2:304-6.

Pillai CSG, Jasmine S. The coral fauna of Lakshadweep. In: marine living resources of the union territory of Lakshadweep - an indicative survey with suggestions for development. Bull Cent Mar Fish Res Inst. 1989;43:178-95.

Prabhakaran MP, Bijoy Nandan S, Jayachandran PR, Pillai NGK. Species diversity and community structure of ichthyofauna in the seagrass ecosystem of Minicoy atoll, Lakshadweep, India. Indian J Geo-Mar Sci. 2013:42:349-59.

Rajan R, Satyanarayana C, Raghunathan C, Koya SS, Ravindran J, Manikandan B, et al. Status and review of health of Indian coral reefs. J Aquat Biol Fisheries. 2015:3:1-14.

Randall JE, Bineesh KK. Review of the fishes of the genus Pempheris (Perciformes: Pempheridae) of India, with description of a new species and a neotype for P. mangula Cuvier. J Ocean Sci Found. 2014;10:20-40.

Rao GC. Lakshadweep: General features. In: Fauna of Lakshadweep. Zool Surv India, Kolkata; 1991. p. 5-40.

Rogers A, Blanchard JL, Mumby PJ. Fisheries productivity under progressive coral reef degradation. J Appl Ecol. 2017;55(3):1041-9. https://doi.org/10.1111/13 65-2664.13051.

Sahayak S, Joshi KK, Murty VS. Taxonomic review of the genera Balistoides, Pseudobalistes and Parabalistes of the family Balistidae with redescription of species occurring in Indian seas. Indian J Fish. 2014;61:19-27.

Sirajudheen TK, Khan JK. Freshwater pond ecosystems and ichthyofaunal diversity of Lakshadweep Islands, India. J Aqua Biol Fish. 2014;2:691-6.

Sluka RD, Lazarus S. Groupers and wrasses of Minicoy Island, Lakshadweep, India. Newsletter of the Groupers \& Wrasses specialist group IUCN. 2006; 9:3-4.

Van der Laan R, Fricke R, Eschmeyer WN. Eschmeyer's Catalog of Fishes: Classification. 2019. http://www.calacademy.org/scientists/catalog-of-fishesclassification/. Accessed 15 Oct 2019

Venkateswarlu T, llango K. On a collection of fishes from Lakshadweep Islands. Acta Icth Pisc. 1982;12(2):33-9. https://doi.org/10.3750/AIP1 982.12.2.03. 
Vinoth TTR, Gopi MAK, Dhaneesh KV. First record of yellowbelly damselfish Amblyglyphidodon leucogaster (Bleeker, 1847) from the Lakshadweep, India. World J Fish Mar Sci. 2012. https://doi.org/10.5829/idosi.wjfms.2012. 04.05.611.

Yadav S, Alcoverro T, Arthur R. Coral reefs respond to repeated ENSO events with increasing resistance but reduced recovery capacities in the Lakshadweep archipelago. Coral Reefs. 2018;37(4):1245-57. https://doi.org/10.1007/s00338018-1735-5.

\section{Publisher's Note}

Springer Nature remains neutral with regard to jurisdictional claims in published maps and institutional affiliations.

- fast, convenient online submission

- thorough peer review by experienced researchers in your field

- rapid publication on acceptance

- support for research data, including large and complex data types

- gold Open Access which fosters wider collaboration and increased citations

- maximum visibility for your research: over $100 \mathrm{M}$ website views per year

At $\mathrm{BMC}$, research is always in progress. 